
ISSN 1678-9199.

\title{
ANTIBACTERIAL ACTIVITY OF Rhynocoris marginatus (FAB.) AND Catamirus brevipennis (SERVILE) (HEMIPTERA: REDUVIIDAE) VENOMS AGAINST HUMAN PATHOGENS
}

SAHAYARAJ K. (1), BORGIO J. F. (1), MUTHUKUMAR S. (1), ANANDH G. P. (1)

(1) Crop Protection Research Centre, Department of Advanced Zoology and Biotechnology, St. Xavier's College, Tamil Nadu, India.

ABSTRACT: The reduviid predators Rhynocoris marginatus (Fab.) and Catamirus brevipennis (Servile) use their venoms to paralyze their preys. We detected the antibacterial activity of $R$. marginatus and $C$. brevipennis venoms against seven Gram-negative and four Gram-positive bacteria by using the disc diffusion method. Rhynocoris marginatus venom exhibited antibacterial activity against four Gramnegative bacteria (Escherichia coli, Pseudomonas aeruginosa, Proteus vulgaris, Salmonella typhimurium) and one Gram-positive (Streptococcus pyogenes). Catamirus brevipennis venom showed antibacterial activity against six Gramnegative (Escherichia coli, Proteus mirabilis, Pseudomonas aeruginosa, Klebsiella pneumoniae, Proteus vulgaris, and Salmonella typhimurium) and three Gram-positive (Bacillus subtilis, Staphylococcus aureus, and Bacillus sphaericus) bacteria. Both C. brevipennis (90.91\%) and $R$. marginatus (45.45\%) venoms were more effective against Gram-negative bacteria (80\% and 70\% for R. marginatus and C. brevipennis, respectively). The venoms of both reduviid predators are composed of low molecular weight proteins (7-33 kD).

KEY WORDS: antibacterial activity, reduviid saliva, protein content, peptides.

\section{CORRESPONDENCE TO:}

KITHERIAN SAHAYARAJ, Crop Protection Research Centre, Department of Advanced Zoology and Biotechnology, St. Xavier's College, Palayamkottai, 627-002, Tamil Nadu, India. Email: ttn ksraj@sancharnet.in. 


\section{INTRODUCTION}

Reduviids have been recognized as important natural enemies against several field crop pests, especially hemipteran and lepidopteran pests (23-27). Rhynocoris marginatus (Fab) and Catamirus brevipennis (Servile) are polyphagous, multivoltine, entomophagous and crepuscular bugs. The vast majority of venomous arthropods are predators and feed exclusively on living prey which can be other arthropods, mainly insects (32). Fabre (9) demonstrated that the insect oral secretion could be paralyzant. Reduviid predators immobilize their prey by injecting venomous saliva into them $(1,13)$.

The large number of antibacterial molecules that are used as therapeutic agents target the bacterial metabolic machinery. The salivary venom of reduviids consists of digestive enzymes, which immobilize the prey and help in its external digestion $(3,5)$. In literature, there are reports on the biochemistry of venoms from reduviids such as Peirates affinis Serville (6), Platymeris rhadamanthus [Gerst] (7), Acanthaspis pedestris [Stal] (19), Haematorrhophus nigroviolaceus [Reuter] (31), Holotrichius innesi [Horrvath], Peirates turpis [Walker], Agriosphodrus dohrni [Stal] and Isyndus obscurus [Dallas] (10), but none from C. brevipennis and R. marginatus.

Venom from predators including reduviids has been a great source of novel peptides with a notable potential for agricultural and medicinal use. The toxic saliva of predatory assassin bugs contains a complex mixture of small and large peptides for diverse uses such as immobilizing and defending against competitors and predators. Most research on venoms has focused on the identification, isolation and purification of proteins and peptides with pharmacological activity like neurotoxins $(8,20,22)$ and antimicrobial peptides, whose presence in the venom has been suggested to be a defense mechanism against infections arisen during ingestion of the prey $(29,30)$. The prey immune system not only plays a major role in dealing with large foreign bodies, but also eliminates microorganisms from its hemocoel. For the predator, it may be advantageous to prey using venom with antimicrobial factors, which could help to protect immunocompromised preys from opportunistic pathogens. This strategy could contribute to the survival of predators. Broad-spectrum antimicrobial activity has been reported for venom or its peptides purified from spiders such as Cupiennius salei (12), Vespa crabro (15), Anoplius samariensis (14), and Protopolybia exigua [Saussure] (18). Antibacterial activity has been widely reported 
in venoms from different snakes including Pseudechis australis (28). The presence of these antimicrobial peptides in venom has been suggested to be a defense mechanism against infections that may arise with the ingestion of prey (30).

As far as we are aware, antibacterial activity in reduviid venom has not been reported. Thus, this study was undertaken to verify the role of antimicrobial activity of two reduviids venoms on selected human pathogens.

\section{MATERIALS AND METHODS}

\section{Reduviid collection and rearing}

The reduviid Rhynocoris marginatus and Catamirus brevipennis were collected from Sivanthipatti agroecosystems ( $77^{\circ} 47^{\prime} \mathrm{E}$ and $\left.8^{\circ} 30^{\prime} \mathrm{N}\right)$, Tirunelveli District, Tamil Nadu, India. They were reared on fifth instar Spodoptera litura (Fab.) larvae kept in plastic containers (7X6) under laboratory condition $\left(28 \pm 2^{\circ} \mathrm{C}, 70 \%-80 \% \mathrm{RH}\right.$, and 11 dark : 13 light).

\section{Venom collection}

Venom was milked using a capillary tube by simply pressing the insects abdomen with the hands. The venom collected from both male and female was stored at $4^{\circ} \mathrm{C}$ for further study.

\section{Bacterial cultures}

Escherichia coli (NCIM - National Collection of Industrial Microorganisms, 2068), Pseudomonas aeruginosa (NCIM 2862), Salmonella typhimurium (NCIM 2501), Klebsiella pneumoniae (NCIM 2098), Proteus mirabilis (NCIM 3011), Bacillus subtilis (NCIM 2063), Staphylococcus aureus (NCIM 2079), Bacillus sphaericus (NCIM 3019), Proteus vulgaris (NCIM 2001), Enterobacter aerogenes (NCIM 2003), and Streptococcus pyogenes (NCIM 2943) were obtained from the Biochemical Division of National Chemical Laboratory, Pune, Maharastra, India. The strains were routinely cultured and maintained in nutrient agar.

\section{Antibacterial bioassay}

The venom antibacterial activity was tested against the eleven pathogenic bacteria mentioned above using the disc diffusion method (2). Inocula were prepared from 
exponential-phase culture in nutrient broth. Nutrient agar plates were prepared and inocula were seeded by the cotton swab method. Venoms were applied to sterile disc (Hi-Media, Mumbai), dried and placed on the seeded agar plates; samples were run in duplicate. As positive control we used standard antibiotic discs (10 $\mu \mathrm{g} / \mathrm{ml}$ each): penicillin for Escherichia coli, Pseudomonas aeruginosa, Bacillus subtilis, Bacillus sphaericus, Streptococcus pyogenes; amikacin for Proteus mirabilis, Klebsiella pneumoniae; carbenicillin for Proteus vulgaris; cephalexin for Enterobacter aerogenus; methicillin for Staphylococcus aureus; and ampicillin for Salmonella typhimurium. Phosphate buffered saline (PBS, $10 \mu \mathrm{g} / \mathrm{ml}$ ) was used as negative control. After 24 hours of incubation at $37^{\circ} \mathrm{C}$, the diameter of inhibition zones (IZ) surrounding the disc formed by diffusion of the venom was measured. From the results, the activity index $(\mathrm{Al})$ was calculated using the following formula: $\mathrm{Al}=$ venom IZ (mm) / standard IZ ( $\mathrm{mm})$.

\section{Protein concentration}

Protein content in the venom samples was estimated by using bovine serum albumin as standard at $610 \mathrm{~nm}(17)$.

\section{Gel electrophoresis}

SDS-PAGE was performed using 12\%-acrylamide gel at $120 \mathrm{~V}$ and $20 \mathrm{~mA}$ (16). Venom samples were dissolved in $20 \mu$ of double distilled water plus $5 \mu$ l of sample buffer $(0.001 \%$ mercaptoethanol and $75 \%$ of $0.313 \mathrm{M}$ Tris- $\mathrm{HCl}: 10 \%$ glycerol) and $0.001 \%$ bromophenol blue $(\mathrm{pH} 6.8)$. They were boiled for two minutes, shaken in vortex for 30 seconds and applied to the gel. After electrophoresis, gels were stained with $0.25 \%$ Coomassie Brilliant Blue R250 solution (containing 50\% methanol and $12 \%$ acetic acid) and destained with $30 \%$ methanol and $10 \%$ acetic acid to reveal proteins. To estimate molecular weights, we used standard molecular weight markers, namely Genei SDS 70L kit (PMW-B standard, Genei Pvt. Ltd., Bangalore, India). 


\section{Statistical analysis}

The activity index (Al) of the reduviid venoms was converted to correlation coefficient using the Statistica software. Protein content was subjected to Duncan's Multiple Range Test (DMRT); values were considered significant at 5\% level.

\section{RESULTS}

The sensitivity of 11 bacterial strains against the two reduviid predators Rhynocoris marginatus and Catamirus brevipennis venoms was assessed. Both venoms showed antibacterial activity against the 11 bacterial strains tested. Moderate sensitivity percentage was observed with Gram-negative organisms (70\%) followed by the Gram-positive (30\%) against C. brevipennis venom. The highest sensitivity was recorded for Gram-negative (80\%) followed by Gram-positive microorganisms (20\%) against $R$. marginatus venom.

Table 1 shows the antibacterial spectrum of adult $R$. marginatus and $C$. brevipennis venoms in terms of inhibition zone (IZ) and activity index (AI). Phosphate buffered saline (PBS) had no inhibitory effect on the bacteria tested. Reduviid venom generally inhibits the growth of Gram-negative as well as Gram-positive bacteria. Catamirus brevipennis venom showed antibacterial activity against all the tested bacteria, except for Streptococcus pyogens. Its Al was the highest against Proteus mirabilis (0.52) followed by Proteus vulgaris (0.49) and Enterobacter aerogenes (0.33). Rhynocoris marginatus venom showed maximum Al against Escherichia coli (0.56), followed by Pseudomonas aeruginosa (0.44), Proteus vulgaris (0.36), and Salmonella typhimurium (0.32). However, no inhibitory effect was recorded against Proteus mirabilis, Bacillus subtilis, Klebsiella pneumoniae, Enterobacter aerogenes, Staphylococcus aureus, and Bacillus sphaericus. Comparatively, C. brevipennis venom had broad-spectrum and higher antibacterial activity than $R$. marginatus venom (Table 1 ). The activity indexes of $C$. brevipennis and $R$. marginatus venoms were negatively correlated $(-0.18, p=0.615453)$.

Total protein content of the tested reduviid venoms was analyzed using the Lowery method, being higher in the venoms from female $(85.71 \mu \mathrm{g} / \mathrm{ml})$ and male $(26.6 \mu \mathrm{g} / \mathrm{ml})$ C. brevipennis than in those from female $(52.8 \mu \mathrm{g} / \mathrm{ml})$ and male $(22.9 \mu \mathrm{g} / \mathrm{ml}) R$. marginatus; they were statistically significant at 5\% level according to the DMRT. Protein profiles of venoms from male and female $R$. marginatus showed two different 
molecular weight polypeptides. Between the two polypeptides, 7-kD polypeptides were common in both male and female venoms. The remaining band was different between sexes: $14 \mathrm{kD}$ for male and $16 \mathrm{kD}$ for female. Protein profile of male $C$. brevipennis venom also showed two polypeptides of different molecular weights and that of female C. brevipennis venom showed six polypeptides of different molecular weights. Two polypeptides (18 and $21 \mathrm{kD}$ ) were common for both sexes of $C$. brevipennis. However, 33-kD, 30-kD, 25-kD and 23-kD polypeptides were observed only in females.

Table 1: Inhibition zone (IZ; mm) and activity index (AI) of Rhynocoris marginatus and Catamirus brevipennis venoms against selected human pathogens.

\begin{tabular}{l|c|c|c|c|c}
\hline \multirow{2}{*}{ Microorganisms used } & \multirow{2}{*}{ Standard } & \multicolumn{2}{|l|}{$\begin{array}{l}\text { Rhynocoris } \\
\text { marginatus } \\
\text { venom }\end{array}$} & \multicolumn{2}{l}{$\begin{array}{l}\text { Catamirus } \\
\text { brevipennis venom }\end{array}$} \\
\cline { 3 - 6 } & & $\mathrm{IZ}$ & $\mathrm{Al}$ & $\mathrm{IZ}$ & $\mathrm{Al}$ \\
\hline Escherichia coli & 17 & 9.6 & 0.56 & 5.5 & 0.32 \\
\hline Proteus mirabilis & 21 & - & - & 10.9 & 0.52 \\
\hline Pseudomonas aeruginosa & 17 & 7.5 & 0.44 & 4.08 & 0.24 \\
\hline Bacillus subtilis & 17 & - & - & 4.25 & 0.25 \\
\hline Klebsiella pneumoniae & 21 & - & - & 4.41 & 0.21 \\
\hline Proteus vulgaris & 22 & 8.0 & 0.36 & 10.86 & 0.49 \\
\hline Enterobacter aerogenes & 18 & - & - & 5.94 & 0.33 \\
\hline Staphylococcus aureus & 18 & - & - & 3.85 & 0.21 \\
\hline Bacillus sphaericus & 17 & - & - & 3.97 & 0.23 \\
\hline Streptococcus pyogenes & 17 & 8.5 & 0.50 & - & - \\
\hline Salmonella typhimurim & 23 & 7.5 & 0.33 & 4.18 & 0.18 \\
\hline
\end{tabular}

- no activity was observed.

\section{DISCUSSION}

From the results, it is very clear that the antibacterial activity of the reduviid venoms differed according to the bacterial species used. These data confirm the general features of Gram-positive and Gram-negative antibacterial proteins, which can induce non-specific immunity in insects (4). Differences in the susceptibility of the tested bacteria can be attributed to the molecular characteristics of the antibacterial factors present in the reduviid venom. Insect antibacterial factors are fairly nonspecific in nature. According to previous studies, insect hemolymph showed a broadspectrum antibacterial action (2). The present study evidences that the peptides 
present in R. marginatus and C. brevipennis venoms might be involved in their antibacterial activity. However, antibacterial activity of C. brevipennis was not detected against a Gram-positive bacterium (Streptococcus pyogenes). Similarly, antibacterial activity of $R$. marginatus was not detected against the Gram-positive bacteria Bacillus subtilis, Staphylococcus aureus, and Bacillus sphaericus. So, to detect antibacterial effect against both Gram-positive and Gram-negative bacteria, using the plate growth assay, a relatively large amount of proteins from $R$. marginatus and C. brevipennis venoms is required. Plate growth assay method is generally used to detect venom antibacterial activity. Both $R$. marginatus and $C$. brevipennis venoms are comprised of many proteins and the proportion of these proteins responsible for the antibacterial activity is not known. Hence this type of study is a prerequisite to isolate and identify the antibacterial proteins present in the reduviid venom. The antibacterial activity detected could be due to one or several peptides. Earlier findings reported that some or all of these activities might be due to the non-selective cytotoxic venom protein melittin, an abundant polypeptide in the venom of the honeybee Apis mellifera (11). Recently, it has been reported that the presence of protopolybia in Protopolybia exigua (Saussere) venom is responsible for its antibacterial activity (18).

Many of the characterized insect antimicrobial peptides inhibit both Gram- positive and Gram-negative bacteria (4). However, short-chain proline-rich antimicrobial peptides have been found to be active mainly against Gram-negative bacteria. Peptides with $\sim 12$ and/or $\sim 13$ residues exhibited potent broad-spectrum antibacterial activities. These include indolicidin, bacteriocins and tigerinins (21). Generally, the peptides bind to the lipopolysaccharides layer in the outer membrane of Gramnegative bacteria and disrupt its structure, which allows the entrance of peptide molecules to the inner membrane. The peptides insert into the inner membrane and break its permeability barrier, which results in cell death. The identified peptides have been used as drugs. To determine whether $R$. marginatus and $C$. brevipennis venoms inhibit exclusively Gram-negative bacteria, further studies are needed using a wider spectrum of Gram-positive and Gram-negative bacteria. 


\section{ACKNOWLEDGMENTS}

Our sincere thanks to Rev. Dr. A. Antonysamy S. J., Principal, and Prof. M. Thomas

Punithan, Head of the Department of Advanced Zoology and Biotechnology, St. Xavier's College, Palayamkottai, Tamil Nadu, India, for the laboratory facilities. Senior author acknowledged CSIR and DST, Govt. of India for the financial assistance,

\section{REFERENCES}

1 AMBROSE DP. Assassin bugs. Oxford and IBH Publishing Co. Pvt. Ltd., 1998: 306.

2 BLONDELLE SE., HOUGHTEN RA. Hemolytic and antimicrobial activites of the 24 individual omission analogs of melittin. Biochem., 1991, 30, 4671-8.

3 BLUM SM. Biochemical defense of insects. In: ROCKSTEIN M. Ed. Biochem. Insects. New York: Academic Press, 1978: 465-513.

4 BULET P., HETRU C., DIMARCQ J., HOFFMAN D. Antimicrobial peptides in insects; structure and function. Dev. Comp. Immunol., 1999, 23, 329-2244.

5 COHEN AC. Feeding adaptations of some predaceous Hemiptera. Ann. Entomol. Soc. Am., 1990, 83, 1215-23.

6 EDWARDS JS. Spitting as a defensive mechanism in a predatory reduviid. Eds. Proceeding of International Congress of Entomology. 11.ed. Vienna, 1960, 3, 259-63.

7 EDWARDS JS. The action and composition of the saliva of an assassin bug Platymeris rhadamanthus Gaerst (Hemiptera: Reduviidae). J. Exp. Biol., 1961, 38, 61-77.

8 ESCOUBAS P., DIOCHOT S., CORZD G. Structure and pharmacology of spider venom neurotoxins. Biochimie, 2000, 82, 893-907.

9 FABRE JH. The glow-worm and other beetles. Lightning Source Inc. La Vergne TN, USA, 2002, 105-12.

10 GERARDO C., SALUMI A., AKAHANE TW., YOSHIHISA K., TOMNI W. Novel peptides from assassin bugs (Hemiptera: Reduviidae): isolation, chemical and biological characterization, FEBS Lett., 2001, 499, 256-61.

11 HABERMANN E., JENTSCH J. Sequential analysis of melittin from triptych and peptic fragments. Biochem. Zeitschrift, 1967, 348, 37-50. 
12 HAEBERLI S., KUHN-NENTWING L., SCHALLER J., NENTWING W. Characterization of antibacterial activity of peptides isolated from the venom of the spider Cupiennius salei (Araneae: Ctenidae). Toxicon, 2000, 38, 373-80.

13 HARIDASS ET., ANANTHAKRISHNAN, TN. Functional morphology of the salivary system in some Reduviid (Insecta: Heteroptera). Proc. Indian Acad. Sci., 1981, 90, 145-60.

14 KONNO K., HISADA M., FONTANA R., LORENZI CCB., NAOKI H., ITAGAKI Y., MIWA A., KAWAI N., NAKATA Y., YASUHARA Y., NETO JR., DE AZEVEDO WF., PALMA JRMS., NAKAJIMA T. Anoplin, a novel antimicrobial peptide from the venom of the solitary wasp, Anoplius samariensis. Acta Biochem. Biophys., 2001, 1550, 70-80.

15 KRISHNAKUMARI V., NAGARAJ R. Antimicrobial and hemolytic activities of crabrolin, a 13-residue peptide from the venom of the European hornet, Vespa crabao, and its analogs. J. Peptide Res., 1997, 50, 88-93.

16 LAEMMLI UK. Cleavage of structural proteins during the assembly of the head of bacteriophage T4. Nature, 1970, 277, 680-5.

17 LOWERY OH., ROSEBROUGH NJ., FARR AL., RANDELL RJ. Protein measurement with from folin phenol reagent. J. Biochem., 1951, 193, 265-75.

18 MENDES MA., SOUZA BM., PALARA MS. Structural and biological classification of 3 novel mastoparan peptides from the venom of the neotropical social wasp Protopolybia exigue (Saussme). Toxicon., 2005, 45, 101-6.

19 MORRISON NM. Gel electrophoretic studies with reference to functional morphology of the salivary glands of Acanthaspis pedestris Stal. (Insecta: Heteroptera: Reduviidae). Proc. Indian Acad. Sci. Anim. Sci., 1989, 98, 16773.

20 PIEK T. Neurotoxins from venoms of the Hymenoptera-twenty-five years of research in Amsterdam. Comp. Biochem. Physiol. C-Pharmacol. Toxicol. Endocrinol., 1990, 96, 223-33.

21 PURNA SAI K., JEGANATHAN MU., VAIRAMANI M., RAJU NP., SHARMA BAI A., NAGARAJ., SITARAM NJ. Tigerinins: Novel antimicrobial peptides from the Indian frog Rana tigerina. J. Biol. Chem., 2001, 276, 2701-7.

22 RASH LD., HODGSON EC. Pharmacology and biochemistry of spider venoms. Toxicon, 2002, 40, 225-54. 
23 SAHAYARAJ K. Bio-efficacy and development of a reduviid predator, Rhinocoris marginatus, on Spodoptera litura. Int. Arach. News Lett., 1995, 15, 56-7.

24 SAHAYARAJ K. Biopesticides - an Indian scenario. Agrob. News Lett., 2002, 1, 26-9.

25 SAHAYARAJ K. Capturing success by reduviid predators Rhynocoris kumarii and Rhynocoris marginatus on different age groups of Spodoptera litura, a polyphagous pest (Heteroptera: Reduviidae). J. Ecobiol., 1994, 6, 3, 221-4.

26 SAHAYARAJ K. Evaluation of biological control potential of Rhynocoris marginatus on four groundnut pests under laboratory conditions. Int. Arach. News Lett., 2000, 20, 72-4.

27 SAHAYARAJ K. Field evaluation of Rhynocoris marginatus (Fab.) against two groundnut defoliators. Int. Arach. News Lett., 1999, 19, 41-2.

28 SEXTON FW., WEINSTEIN SA. Antibacterial effects of different snake venoms: purification and characterization of antibacterial peptides from Pseudechis australis venom. Toxicon, 1991, 29, 1129-41.

29 THOMAS RG., POUGH FH. The effect of rattlesnake venom on digestion of prey. Toxicon, 1979, 17, 221-8.

30 YAN L., ADAMS ME. Lycotoxins, antimicrobial peptides from venom of the wolf spider Lycosa carolinensis. J. Biol. Chem., 1998, 273, 2059-66.

31 ZERACHIA T., BERGMANN F., SHULOV A. Pharmacological activities of the venom of the predaceous bug Holotrichius innessi (Heteroptera: Reduviidae). In: KAISER E. Ed. Anim. Plant toxins., 1973: 143-6.

32 ZLOTKIN E. Toxins derived from arthropod venoms specifically affecting insects. In: KERKUT GA., GILBERT LT. Eds. Comprehensive insect Physiol. Biochem. Pharmacol. v.10. Pergamon: Oxford, 1984. 